\title{
Clear cell acanthoma of the areola and nipple: clinical, histopathological, and immunohistochemical features of two Brazilian cases
}

\author{
Acantoma de células claras da aréola e do mamilo: aspectos clínicos, \\ histopatológicos e imuno-histoquímicos de dois casos brasileiros
}

\author{
Rossana Ruth Garcia da Veiga ${ }^{1}$ \\ Josie Eiras Bisi dos Santos ${ }^{2}$ \\ Maraya de Jesus Semblano Bittencourt ${ }^{2}$
}

\author{
Renata Silva Barros ${ }^{2}$ \\ José Maria de Castro Abreu Junior ${ }^{3}$ \\ Mario Fernando Ribeiro de Miranda ${ }^{4}$
}

\begin{abstract}
Clear cell acanthoma or Degos' acanthoma is a distinct disease concerning its clinical, histopathological, and immunohistochemical features. Its pathologic nature - whether neoplastic or reactive - is still under dispute among researchers. The disease shows a chronic course and often presents with a single papulonodular lesion on the lower limbs of adults. However, cases with multiple lesions, sometimes occurring in an eruptive fashion, and with clear variation in the size and shape of the cutaneous lesions have been reported. So far, five cases in which the lesions were exclusively located in the nipple area have been reported, all in Korean women. Four of these cases mimicked eczema and one, a polypoid nodule. The aim of this article is to present clinical, histopathological, and immunohistochemical features of two additional cases in Brazilian women with similar nipple topography.

Keywords: Acanthoma; Breast; Eczema; Histology; Nipples

Resumo: O acantoma de células claras ou acantoma de Degos é uma doença bem individualizada quanto aos seus aspectos clínicos, histopatológicos e imuno-histoquímicos. Sua natureza patológica - se neoplásica ou reativa - ainda é debatida por pesquisadores. De evolução crônica, ocorre predominantemente nos membros inferiores de adultos, em geral como lesão papulonodular única. Entretanto, foram observados casos com lesões múltiplas, por vezes de caráter eruptivo, e com notável variação de tamanho e forma das eflorescências cutâneas. Há relatos de cinco casos com localização exclusiva na aréola e no mamilo, quatro simulando eczema e um como nódulo polipoide; todos ocorridos em mulheres coreanas. O objetivo deste trabalho é apresentar os aspectos clínicos, histopatológicos e imuno-histoquímicos de dois novos casos da doença, com idêntica topografia areolomamilar, observados em mulheres brasileiras.

Palavras-chave: Acantoma; Eczema; Histologia; Mama; Mamilos
\end{abstract}

\footnotetext{
Received on 27.11.2011.

Approved by the Advisory Board and accepted for publication on 29.11.2011

* Study conducted at the Dermatology Service, Instituto de Ciências da Saúde, Universidade Federal do Pará School of Medicine, and at Private Offices, Belém (PA), Brazil

Conflict of interest: None

Financial funding: None

MD, MSc, Dermatologist - Assistant Professor of Dermatology, School of Medicine, Federal University of Pará (Universidade Federal do Pará - UFPA) - Belém (PA), Brazil.

MD, Dermatologist - Private Practitioner, Belém (PA), Brazil.

MD, Pathologist - Pathologist at João de Barros Barreto University Hospital, School of Medicine, Federal University of Pará (UFPA) - Belém (PA), Brazil.

MD, Dermatologist, Dermatopathologist - Assistant Professor of Dermatology, School of Medicine, Federal University of Pará (UFPA) - Belém (PA), Brazil.

(C)2013 by Anais Brasileiros de Dermatologia
} 
Clear-cell acanthoma (CCA), first described by Degos et al. in 1962, is a rare benign skin lesion which occurs mostly on the lower limbs of middle-aged to elderly individuals, peaking in incidence in the fifth decade of life. ${ }^{1}$ It is usually a solitary red to brown papule, glistening nodule, or dome-shaped plaque measuring $2-20 \mathrm{~mm}$, with a crusted or scaly surface, sometimes oozing a clear fluid or, occasionally, blood. CCA has been clinically described as presenting the 'stuck on' appearance of seborrheic keratosis (SK), the vascular look of a pyogenic granuloma, the scaling and exsudation of an eczema, and the advancing round border of an epithelioma. ${ }^{2}$ Despite these characteristics, CCA is rarely clinically diagnosed prior to biopsy, since basal cell carcinoma (BCC), SK, and squamous cell carcinoma (SCC), among other conditions, are most often suspected. ${ }^{3}$ Regarding these features and the fact that most patients present with a single lesion, CCA was formerly considered neoplastic in nature. However, given its close histopathological resemblance to psoriasis and occasional associations and/or lesion overlapping with several conditions, including psoriasis itself, a reactive/inflammatory process has been favored by many researchers. CCA may occur either as a single or as multiple lesions. ${ }^{4}$ Rare disseminated forms must be differentiated from other eruptive dermatoses such as guttate psoriasis, certain forms of parapsoriasis, sarcoidosis, lichen planus, and granuloma annulare. ${ }^{5}$

The histopathological picture of CCA is quite typical, consisting of epidermal hyperplasia, a slight increase in size of the Malpighian cells - which have a pale cytoplasm -, spongiosis, and parakeratosis. The PAS-positive and diastase-labile pale-cell acanthosis shows a distinct line of demarcation and does not involve either acrosyringia or acrotrichia. ${ }^{6}$ Shared histopathological features with psoriasis include parakeratosis, hypo-/agranulosis, regularly elongated rete ridges, intracorneal/intramalpighian neutrophil aggregates, papillary-dermal edema, and dilated/tortuous capillaries. Immunoreactivity for epithelial membrane antigen (EMA) by clear cells can also assist in defining the diagnosis. ${ }^{7}$ A broad spectrum of tumors composed of large clear cells should be considered in the histopathological differential diagnosis of CCA, including clear-cell hidradenoma, clear-cell syringoma, hidroacanthoma simplex, tricholemmoma, and SCC in situ. ${ }^{8,9}$ The recently described psoriasiform keratosis, in which psoriasiform hyperplasia and intraepithelial neutrophils are seen, may also be considered for the differential diagnosis of CCA. ${ }^{10}$

In some rare instances, CCA has occurred in the nipple area. So far, these cases have only been observed in young Korean women, either mimicking a nipple eczema or presenting a polypoid growth pat- tern. ${ }^{11,12,13}$ The aim of this article is to present the clinical, histopathological, and immunohistochemical features of two additional cases, which were observed in Brazilian women with a similar topography.

\section{PATIENTS AND METHODS}

Case \#1: An apparently healthy 25-year-old dark-skinned female sought medical help in 2004 due to a persistent, pruritic, exsudative, slowly enlarging lesion which had appeared 1 year earlier on her left breast. Dermatological examination revealed a welldemarcated, bright-red, lobulated plaque with an oozing surface on the nipple and areola measuring $4 \times 4$ $\mathrm{cm}$ (Figure 1A). Clinical diagnoses included nipple eczema, mammary Paget's disease, syringadenoma papilliferum, and pemphigus vegetans. Histopathological examination of a first biopsy suggested eosinophil-rich psoriasiform spongiotic dermatitis. Eosinophils also predominated in a cytologic smear. A negative direct immunofluorescence test ruled out pemphigus. Occasional bleeding occurred, and episodes of secondary infection had prompted systemic antibiotic therapies as well as wet dressings of boric acid solution. During a follow-up consultation in 2010, the persistent lesion showed a much larger size of approximately $10 \times 8 \mathrm{~cm}$, a slightly raised, mamillated, wet, and scarcely squamous surface, and some expansion to the surrounding skin (Figure 1B). Although a diagnosis of nipple eczema had been clinically favored, a diagnosis of CCA was proposed after a new biopsy with routine PAS/PAS-diastase and immunohistochemical stainings was performed, as well as a reassessment of recuts from the first biopsy block (Figures 1C-F). No treatment has been effective to date, including $2 \%$ boric acid wet dressings, oral nimesulide, oral and topical antibiotics, topical steroids, and tacrolimus ointment.

Case \#2: An 18-year-old dark-skinned female complained of a pruriginous and quickly growing lesion on her left nipple and areola, which she had noticed 4 months earlier. She was under hormonal replacement therapy for hypothyroidism and also complained of sinusitis. On examination, a $2.0 \times 2.5$ $\mathrm{cm}$ erythematous, infiltrated, erosive plaque with distinct borders and scant clear fluid secretion was observed on the left nipple and areola (Figure 2A). Given the previous experience with case \#1, a clinical diagnosis of CCA was considered and finally confirmed by histology and immunohistochemistry (Figures 2B-F). Some $0.05 \%$ clobetasol cream applied twice a day cleared the lesion within a few weeks. As new relapses followed, the patient herself decided to reapply the cream as necessary. 


\section{METHODS}

One 5-mm punch biopsy was taken from a paracentral area of the plaque in each case. Tissues were formalin-fixed, paraffin-embedded, and processed according to routine protocols. As features strongly suggestive of CCA were observed in hematoxilin-eosin (H-E) stained sections, recuts were provided for PAS and PAS-diastase stains. Taking into account the anatomical area under study, in which clear cells of at least three types may populate epithelial structures (Toker cells, pagetoid-dyskeratosis cells, and signetring cells), and according to a protocol recommended by Ko et al., an immunohistochemical study was performed. ${ }^{14,15}$ Epitope retrieval was carried out by heating $0.01 \mathrm{M}$ citrate buffer in a wet chamber (Pascal Dako, ${ }^{\circledR}$ Carpinteria, California, USA). The activity of endogenous peroxidase was blocked with a 5-minute treatment with 3\% hydrogen peroxide. The following primary antibodies were used: AE1/AE3 (low and high-weight cytokeratins, 1:800), CK- 8 (low-weight cytokeratin 8 , clone $35 \beta \mathrm{H} 11,1: 100)$, CK-1/5/10/14 (high-weight cytokeratins, clone 34ßE12, 1:100), CK-7 (cytokeratin 7, clone OV-TL 12/30, 1:200), CEA (clone II-7, 1:100), EMA (clone E29, 1:400), and S-100 protein (polyclonal, 1:1600), all of them from Dako, ${ }^{\circledR}$ Carpinteria, California, USA. For visualization of streptavidin-biotin conjugates, 3,3'-diaminobenzidine was applied. Adequate negative and positive controls were available, including recuts from an excisional biopsy section of a confirmed case of CCA that had previously occurred on the abdominal wall of a 51-year-old male patient.

\section{RESULTS}

Both cases presented psoriasiform epidermal hyperplasia, slight spongiosis, parakeratosis, hypo/agranulosis, and keratinocytes with enlarged clear cytoplasm in the stratum Malpighi (Figures 1C and 2B). Neutrophils were seen either scattered or forming aggregates among the clear cells and in the stratum corneum (Figure 2D). As the biopsies had been taken from paracentral areas of the plaques in both patients, the margins of the lesions were not available for assessment. The clear cell population strongly stained with PAS, but failed to stain after diastase digestion, confirming their glycogen content (Figures $1 \mathrm{D}$ and $1 \mathrm{E})$. In both cases, immunoreactivity of the pale cells to EMA and of all keratinocytes (including pale cells) to AE1/AE3 and $34 \beta \mathrm{E} 12$ were observed (data not shown) (Figures $1 \mathrm{~F}$ and $2 \mathrm{~F}$ ). 35 $\beta \mathrm{H} 11$, CK-7, CEA, and S-100 stains yielded negative results. Identical results were observed in the case-control material. Therefore, we concluded that both cases fulfilled the required criteria for a diagnosis of CCA to be made.

\section{DISCUSSION}

CCA on the nipple/areola area was first reported in 1999 in a 23-year-old Korean woman, who also suffered from atopic dermatitis. The authors considered the case unusual, since it presented as a nipple eczema, and suggested including CCA in the clinical differential diagnosis of recalcitrant nipple eczema. ${ }^{11}$ Three additional cases of CCA on the nipple and areola areas in young Korean women were subsequently reported, one of them as a $2 \times 2 \mathrm{~cm}$ sized sharply-delineated erythematous plaque, and the other two as erythematous scaly patches. ${ }^{12}$ A further case of a 14-yearold atopic Korean girl with a slow-growing, itchy, polypoid nodule on the left nipple was reported. ${ }^{13}$ In addition to the cases with nipple/areola localization published to date, Kerl reported on a female patient with CCA on the right breast without specifying the area. ${ }^{16}$ Lesions located on the sternum and costal archs were present in the case of a 52-year-old male with multiple lesions reported by Fandrey et al. ${ }^{9}$ Another case of pigmented CCA on the left upper chest of a 60-year-old Korean man whose original picture clearly shows proximity to the areola was reported by Choe et al. ${ }^{17}$ These cases as well as ours may suggest that the breast area, including the nipple/areola area, represents a site on which, although rarely, CCA may occur. However, we were not able to find in the literature cases of CCA occurring on other apocrine-rich skin sites, such as axillae, perineum, and genitalia.

The major criteria for a diagnosis of CCA to be made were present in our two cases. By means of morphology and histochemical and immunohistochemical tools, we were also able to exclude clear-cell proliferations of other nature, most of them neoplastic, as well as Toker-, signet-ring-, and pagetoid-dyskeratosis-cell proliferations. These latter three cell types are normal constituents or may be eventually present in the nipple/areola complex epidermis. ${ }^{14}$ From a clinical standpoint, we consider that our case \#2 met the classical morphological criteria for CCA, namely, net borders, 'stuck on' appearance, and humid, poorly scaly surface. Erosive areas were also seen both clinically and histopatologically (Figure 2C). On the other hand, case \# 1 showed, during a long-lasting evolution time, outstanding variations in clinical presentation, overlapping with some clinical aspects described in the literature for CCA, especially polypoid, giant, and eczematoid morphologies. A papillomatous surface and pyo-bloody discharge also suggested alternative diagnosis over time, such as pemphigus vegetans and chronic eczema.

Based on its cytokeratin profile in comparison with SK, eccrine poroma, and inflammatory lesions, Cotton et al. stated that CCA should not be a neoplasm. ${ }^{7}$ For instance, CCA stains positively with EMA, 

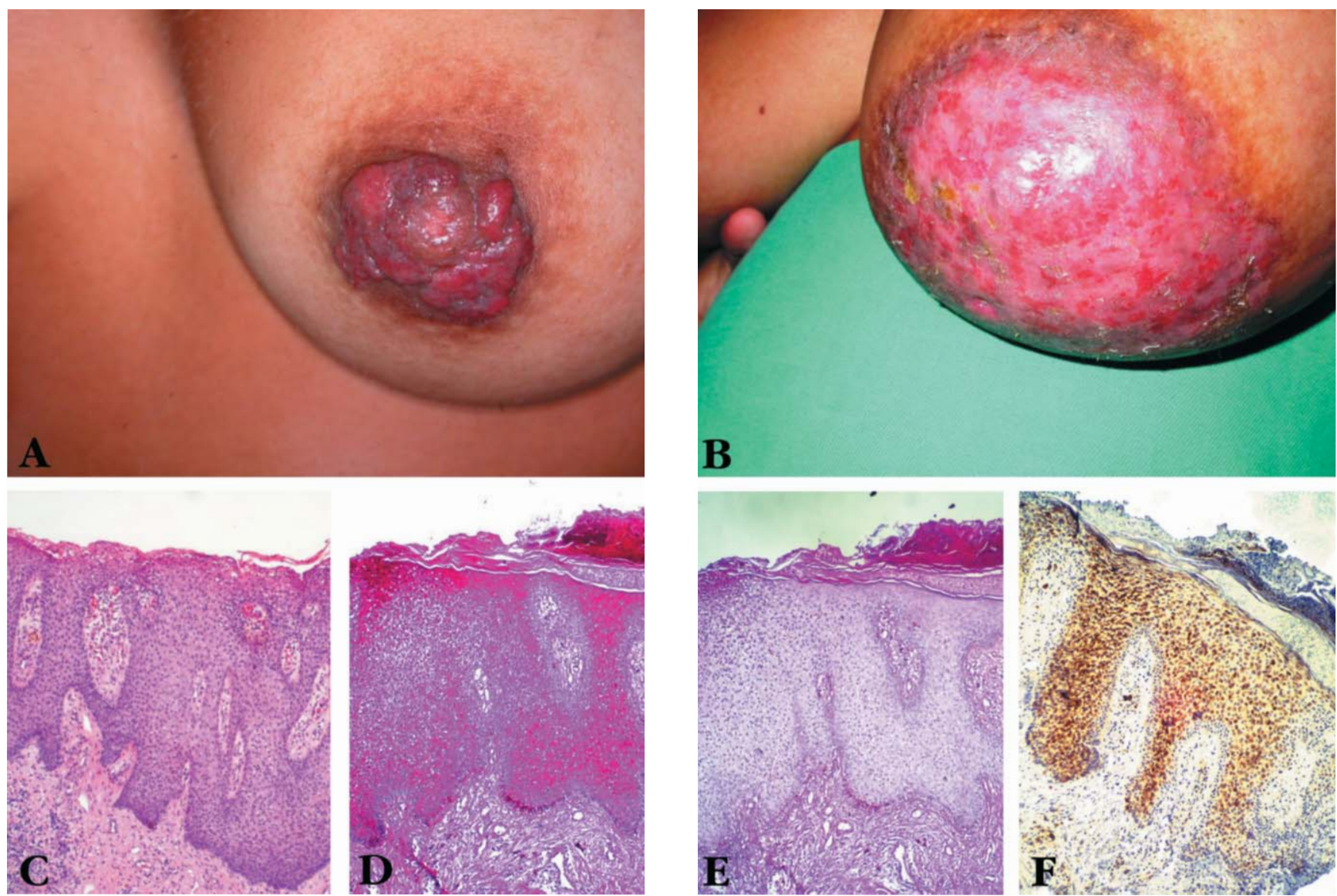

FigURE 1: Case 1: A - A bright-red, lobulated plaque with an oozing-surface on the left nipple and areola (original presentation in 2004); B - Bright erythematous, eczematoid plaque with a slightly mamillated surface and ill-defined hyperchromatic margins (year 2010); C - Psoriasiform hyperplasia with diffuse clear-cell change of keratinocytes in the Malpighian layer and fusion of rete ridges (H-E, original magnification 100x); D - Clear cells stained in red, basal cell layer spared (PAS, original magnification 100x); E - Clear cells failed to stain with PAS after diastase digestion (PAS-diastase, original magnification 100x); F - Intense expression of EMA by clear cells (EMA immunoperoxidase, original magnification 100x)

whereas SK fails to react. ${ }^{7}$ Immunohistochemical characterization of the keratin expression of CCA revealed a staining pattern similar to that of inflammatory dermatoses such as psoriasis, lichen planus, and discoid lupus erythematosus. Thus, some authors speculate that CCA is a localized form of inflammatory dermatosis rather than a neoplasm of epidermal appendages. ${ }^{18}$ Ramos-e-Silva, who presented the first Brazilian case in 1971, proposed the term 'clear-cell acanthosis' for the disease, given both its apparently non-neoplastic nature and the existence of a similar, previously described lesion of the esophageal mucosa named glycogenic acanthosis of the esophagus. ${ }^{19}$ Fukushiro $S$. et al. expanded the concept of pale (clear)-cell acanthosis to define CCA-like epithelial features found in association with conditions such as SK, verrucae, or verrucous keratosis. ${ }^{8}$ Moreover, foci of pale-cell acanthosis have been recently reported in SK and in adja- cent areas of a junctional nevus and a melanoma. ${ }^{15}$ Supporting the inflammatory hypothesis, chronic inflammatory dermatoses, including atopic dermatitis, were found in association with CCA of the nipple area in almost all of the reported cases. ${ }^{13}$ Histological as well as dermoscopic similarities to plaque-type psoriasis may strengthen such viewpoint. Furthermore, several researchers have favored CCA as an inflammatory/reactive process, given its associations, and even overlappings, with preexisting inflammatory dermatoses such as stasis dermatitis, bacterial infections, psoriatic plaques, and trauma. ${ }^{4,6} \mathrm{~A}$ recent observation of histologically proven spontaneous regression in a case of CCA with multiple lesions also reinforces this theory. ${ }^{5}$ For all these reasons, the pathologic nature of CCA still remains under debate.

It is worthy of note that the presence of eosinophils in CCA infiltrates has already been report- 

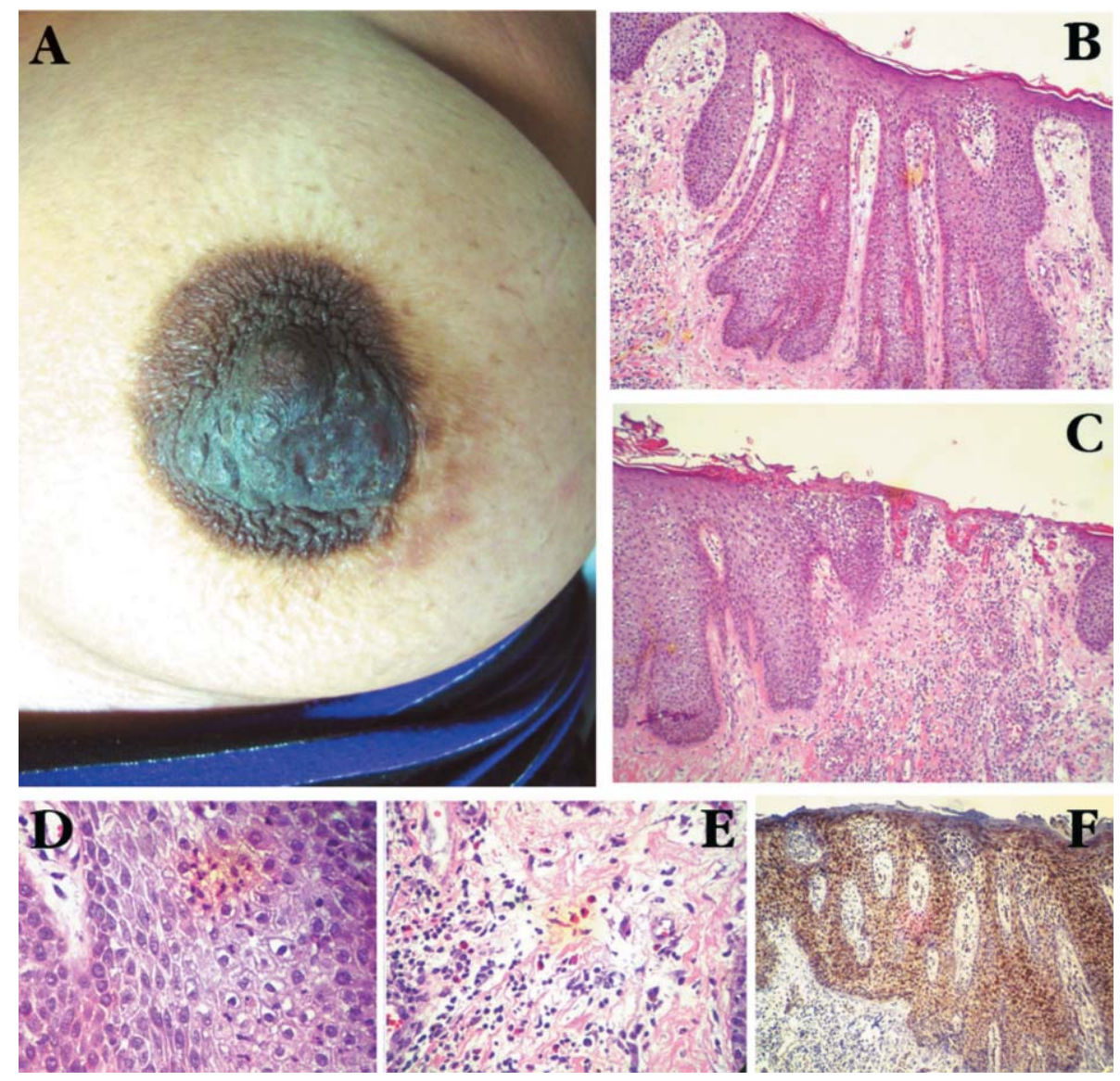

ed in the literature. In a fashion similar to that observed in both of our cases, eosinophils constituted approximately $25 \%$ of the dermal infiltrate in one of the cases reported by Brownstein et al. ${ }^{20}$ Although clear-cell acanthotic margins were not available for assessment in biopsies of both our cases, we consider the following histopathological features, together with the clinical aspects depicted in figures 1 and 2, to be criteria met to render the diagnosis of CCA: (i) glycogen-rich, EMA-positive psoriasiform hyperplasia, (ii) confluent parakeratosis, (iii) hypo-/agranulosis, and (iv) neutrophil infiltrate.

In conclusion, herein are reported two additional cases of CCA on the nipple/areola area of young women. An eosinophil-rich infiltrate observed in both of them represents a rare feature formerly reported in the literature. To the best of our knowledge, they would represent the $6^{\text {th }}$ and $7^{\text {th }}$ cases in the literature and the first cases observed outside Korea.

\section{ACKNOWLEDGMENTS}

The authors wish to thank Dr. Samia Demachki, $\mathrm{MD}, \mathrm{PhD}$, for her immunohistochemical assistance, and Erik Miranda, BSE, MMath Candidate, University of Waterloo, ON, Canada, for competently revising the English manuscript. Their contribution is gratefully appreciated. 


\section{REFERENCES}

1. Degos R, Delort J, Civatte J, Poiares Baptista A. Tumeurépidermiqued'aspectparticulier: acanthomeàcellulesclaires. Ann Dermatol Syphiligr. 1962;89:361-71.

2. Fine RM, Chernosky ME. Clinical recognition of clear-cell acanthoma (Degos). Arch Dermatol. 1969;100:559-63.

3. Morrison LK, Duffey M, Janik M, Shamma HN. Clear cell acanthoma: a rare clinical diagnosis prior to biopsy. In J Dermatol.2010;49:1006-11.

4. Finch TM, Tan CY. Clear cell acanthoma developing on a psoriatic plaque: further evidence of an inflammatory aetiology?Br J Dermatol. 2000;142:842-4.

5. García-Gavín J, Gonzáles-Vilas D, Montero I, Rodriguez-Pazos L, Pereiro MM, Toribio J. Disseminated eruptive clear cell acanthoma with spontaneous regression: further evidence of an inflammatory origin? Am J Dermatopathol. 2011;33:599-602.

6. Degos R, Civatte J. Clear-cell acanthoma: experience of 8 years. $\mathrm{Br} \mathrm{J}$ Dermatol. 1970;83:248-54

7. Cotton DWK, Mills PM, Stephenson TJ, Underwood JCE. On the nature of clear cell acanthomas. Br J Dermatol. 1987;117:569-74.

8. Fukushiro S, Takei Y, Ackerman A. Pale-cell acanthosis: a distinctive histologic pattern of epidermal epithelium. Am J Dermatopathol. 1985;7:515-27.

9. Fandrey K, Rabenhorst S, Fedler R, Frosch PJ. Multiple Klarzellakanthome.Hautarzt. 1995;46:865-8.
10. Walsh SN, Hurt MA, Santa Cruz DJ. Psoriasiform keratosis.Am J Dermatopathol. 2007;29:137-40.

11. Kim DH, Kim CW, Kang SJ, Kim TY. A case of clear cell acanthoma presenting as nipple eczema.Br J Dermatol. 1999;141:950-1.

12. Um SH, Oh CW. Three cases of clear cell acanthoma on nipple and areola. Korean J Dermatol. 2003;41:85-8.

13. Park SY, Jung JY, Na JI, Byun HJ, Cho KH. A case of polypoid clear cell acanthoma on the nipple.Ann Dermatol. 2010;22:337-40.

14. Val-Bernal JF, Diego C, Rodriguez-Villar D, Garijo MF. The Nipple-Areola Complex Epidermis: A prospective systematic study in adult autopsies. Am J Dermatopathol. 2010;32:787-93

15. Ko CJ, Subtil A. Clear (pale) cell acanthosis as an incidental finding. J CutanPathol. 2009; 36:573-577.

16. Kerl H. Das Klarzellakanthom. Hautarzt. 1977;28:456-462.

17. Choe SW, Kim JE, Kim MN, Ro BI, Song KY. A case of pigmented clear cell acanthoma. Ann Dermatol. 2004;16:105-8.

18. Ohnishi T, Watanabe S. Immunohistochemical characterization of keratin expression in clear cellacanthoma. Br J Dermatol 1995;133:186-93.

19. Ramos-e-Silva J. Acantose ("acantoma") de células claras. An Bras Dermatol 1971; 46:109-15.

20. Brownstein MH, Fernando S, Shapiro L. Clear cell acanthoma: clinicopathologic analysis of 37 new cases. Am J ClinPathol. 1973;59:306-11.

\author{
MAILING ADDRESS: \\ Mario F. R. Miranda, MD \\ Av. Nazaré, 1033 / 701 \\ 66040-145, Belém (PA), Brazil \\ E-mail address: mariomir@globo.com
}

How to cite this article: Veiga RRG, Barros RS, Santos JEB, Abreu-Junior JMC, Bittencourt MJS, Miranda MFR. Clear cell acanthoma of the areola and nipple: Clinical, histopathological, and immunohistochemical features of two Brazilian cases. An Bras Dermatol. 2013;88(1):84-9. 